Pak. j. sci. ind. res. Ser. A: phys. sci. 2021 64A(2) 103-109

\title{
Water Study of Physical, Chemical and Heavy Metals Parameters in River Indus and its Tributaries, Sindh, Pakistan
}

\author{
Waqar Ahmad, Arif Zubair, Haq Nawaz Abbasi* and Muhammad Imran Nasir \\ Department of Environmental Science, Federal Urdu University of Arts, Science and Technology, \\ Gulshan-e-Iqbal, Karachi, Pakistan
}

(received December 3, 2019; revised May 14, 2020; accepted June 17, 2020)

\begin{abstract}
This study was conducted to investigate the water quality of the Indus river, Sindh, Pakistan. A total of 41 locations were selected along the Indus river and its tributaries for the collection of surface water samples. Twenty-one physico-chemical parameters and heavy metals were analyzed and the data were interpreted through different statistical techniques. In the current study, eleven parameters including iron, copper, zinc, electrical conductivity (EC), total dissolved solids (TDS), $\mathrm{pH}$, potassium, sodium, nitrate, sulfate, and chloride with an average value $0.13 \mathrm{mg} / \mathrm{L}, 0.04 \mathrm{mg} / \mathrm{L}, 0.16 \mathrm{mg} / \mathrm{L}, 733 \mu \mathrm{S} / \mathrm{L}, 211.2 \mathrm{mg} / \mathrm{L}, 7.6$, $8.9 \mathrm{mg} / \mathrm{L}, 107.4 \mathrm{mg} / \mathrm{L}, 8.01 \mathrm{mg} / \mathrm{L}, 102 \mathrm{mg} / \mathrm{L}, 140 \mathrm{mg} / \mathrm{L}$ respectively and were within permissible limits set by the World Health Organization (WHO) for drinking water. Whereas, average values of cadmium, mercury, lead, total alkalinity (TA), chemical oxygen demand (COD), total hardness (TH) and turbidity were found $0.004 \mathrm{mg} / \mathrm{L}, 0.007 \mathrm{mg} / \mathrm{L}, 0.02 \mathrm{mg} / \mathrm{L}, 920 \mathrm{mg} / \mathrm{L}, 103 \mathrm{mg} / \mathrm{L}, 262 \mathrm{mg} / \mathrm{L}$ and $186.2 \mathrm{NTU}$ respectively, higher than permissible limits. Pearson correlation matrix and cluster analysis were used to understand similarities and differences between variables. The variation in the correlation of different parameters shows the complexity of the water quality.
\end{abstract}

Keywords: water quality, Indus river, statistical analysis

\section{Introduction}

The economic importance of water is an emerging issue worldwide, and there is an evolving development of economic indicators and performance measures (Kalbus et al., 2012). Economics is an important part of developing sustainable resource management practices. The higher value of water now requires greater emphasis to manage supply and demand (De Fraiture and Wichelns, 2010). The changing climate has contributed to greater uncertainty and there is a need for a more structured approach to risk management and water quality (Wilhite et al., 2014).

The Indus is one of the main and longest rivers of Pakistan. From its source Himalayas, it flows through Kashmir along the length of Pakistan to the Arabian sea and covering about 3200 kilometers (Begum, 2011). The river Indus plays an important role in maintaining and developing the economy of the country and act as a backbone in the irrigation network (Yang et al., 2013).

Environmental degradation, along with safe drinking water and lack of basic sanitation facilities, has a huge impact on the health of the people (Capps et al., 2016). It is a fact that the Indus river is polluted due to indiscriminate discharges of untreated municipal waste*Author for correspondence; E-mail: hn.abbasi@yahoo.com water, industrial discharges and agriculture runoff (Azizullah et al., 2011). Most of the municipalities in Sindh province discharge their wastewater into the river Indus without treatment (Memon et al., 2011). Kumar et al. (2013) described in his study that the concentration level of manganese, lead and iron was higher, whereas in another studies carried out by Lashari et al. (2012) showed higher concentration of cadmium and nickel as prescribed by WHO. The aim of the current study is to check the water quality parameters including heavy metals, chemical and physical parameters in Indus river water and its tributaries of province Sindh, Pakistan.

\section{Materials and Methods}

Study area and sampling. The river Indus originates from the Himalayan mountains, runs through Ladakh, Kashmir, Gilgit Baltistan covering the entire length of Pakistan and finally flows out into the Arabian sea. The Indus river is a national and longest river in Pakistan. There is arid to a semi-arid climate in Indus plain and mean monthly temperature vary from $14-28^{\circ} \mathrm{C}$ and 30 $42{ }^{\circ} \mathrm{C}$ during winter and summer seasons, respectively. The annual average precipitation is $90 \mathrm{~mm}$ in the lower Indus plain (Larkana and Jacobabd), whereas, $510 \mathrm{~mm}$ average precipitation occurs in the upper Indus plain (Lahore and Multan). The Indus river basin represents 


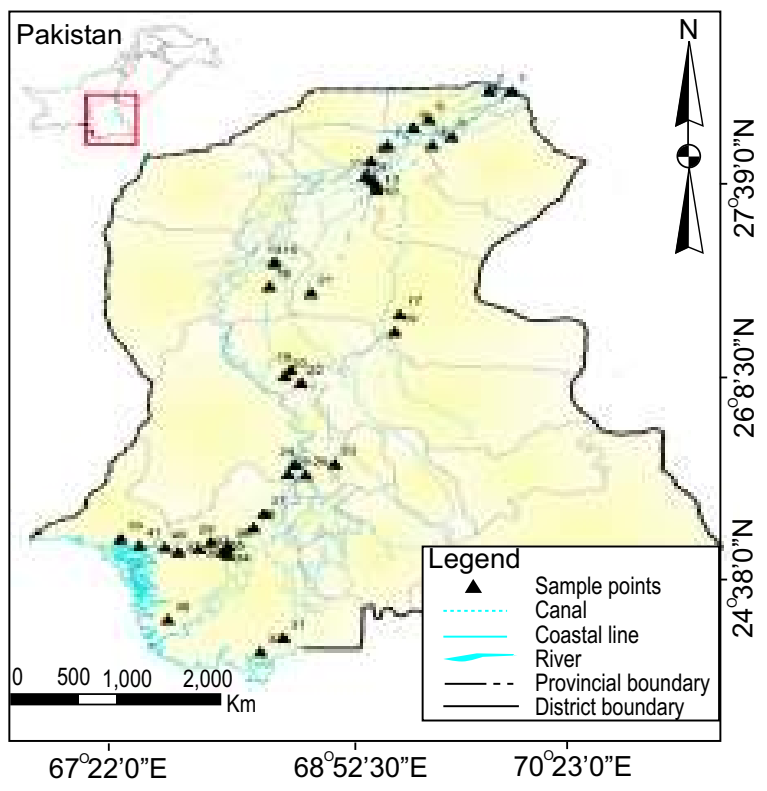

Fig. 1. Location map showing study area and sampling points.

an extensive groundwater aquifer, moreover, waterlogging and salinity are common in agriculture land of lower areas. The study was carried out during March 2017, and forty-one representing sites from Kashmore to Ketibandar along the river Indus and its tributaries were selected for sampling to investigate the water quality (Fig. 1). The water samples were taken in white 1.5 litre polyethylene bottles. The bottles were washed with distilled water and then rinsed twice with water being sampled before filling. Samples were carefully collected to avoid any contamination or deteriorate of sampled water quality. The transfer of samples from the site to the laboratory was carried out according to procedure descibed by Mitra and Kebbekus (2018).

Onsite evaluation. All physical parameters including temperature, $\mathrm{pH}, \mathrm{TDS}, \mathrm{EC}, \mathrm{DO}$, salinity, and turbidity were analyzed at the sampling site during sample collection. The instruments "2100P Portable Turbidimeter" and "Hach Sension 156 Portable Multiparameter" were used for an onsite evaluation.

Laboratory evaluation. Chemical analysis were performed in the laboratory to find out the concentrations of sodium $(\mathrm{Na})$, potassium $(\mathrm{K})$, sulphate $\left(\mathrm{SO}_{4}\right)$, nitrate $\left(\mathrm{NO}_{3}\right)$, chloride $(\mathrm{Cl})$, total alkalinity (TA), total hardness (TH), chemical oxygen demand (COD), iron (Fe), zinc $(\mathrm{Zn})$, copper $(\mathrm{Cu})$, cadmium $(\mathrm{Cd})$, lead $(\mathrm{Pb})$ and mercury $(\mathrm{Hg})$. The titrimetric methods were used to analyze chloride, TA, and TH; flame-photometry for potassium and sodium; spectrophotometry for COD, zinc, sulfate, iron, and nitrate; whereas mercury, lead, cadmium and copper were detected by using atomic absorption spectrophotometer.

Data recording and statistical analysis. Initial data were note-down on paper and then immediately data were transferred to the MS-Excel sheet. Minitab (version 11.12) was used for statistical techniques to achieve comprehensive results.

\section{Results and Discussion}

Descriptive statistics. Table 1 shows the descriptive statistics overview of water samples in the study area. Conductivity, turbidity and temperature vary from 264 to $857 \mu \mathrm{s} / \mathrm{cm}, 0.41$ to $219 \mathrm{NTU}$ and 19.6 to $29.5 \mathrm{C}^{\circ}$, respectively, whereas $\mathrm{pH}$ is mildly alkaline. The average mean $\mathrm{mg} / \mathrm{L}$ values of COD, salinity, DO, TDS, TA and TH are 103, 0.131, 5.25, 211.2, 920 and 262, respectively. Mean cations and anion concentrations occur in the order $\mathrm{Na}>\mathrm{K}$ and $\mathrm{CL}>\mathrm{SO}_{4}>\mathrm{NO}_{3}$ respectively, and order of mean values of heavy metals is zinc $>$ iron $>$ copper $>$ lead $>$ mercury $>$ cadmium.

Pearson correlation matrix. The Pearson Correlation Matrix is a useful statistical technique to point out associations between parameters that show the overall rationality of the data set. Pearson Correlation Matrix also indicates the participation of the individual parameters in many persuade factors, a reality that normally occurs in water chemistry (Helena et al., 2000). The significance level for degrees of freedom was checked by using $r$ table in sequence order.

values greater than 0.349 and less than $0.449(\mathrm{P}<0.05)$; values greater than 0.449 and less than $0.554(\mathrm{P}<0.01)$; values greater than $0.554(\mathrm{P}<0.001)$

The Pearson Correlation Matrix for different parameters of Indus river water and its tributaries are shown in Table 2 . The temperature was negatively correlated with conductivity, TDS, salinity and sodium. The $\mathrm{pH}$ of water samples showed positive significant correlation with dissolved oxygen and negatively correlated with copper. Turbidity was negatively correlated with conductivity, TDS and salinity. Conductivity showed positive significant correlation with TDS $(\mathrm{P}<0.001)$, salinity ( $\mathrm{P}<0.001)$, chloride $(\mathrm{P}<0.001)$, sodium $(\mathrm{P}<0.01)$, sulfate $(\mathrm{P}<0.01)$, potassium $(\mathrm{P}<0.01)$ and $\mathrm{COD}(\mathrm{P}<0.05)$. TDS showed a highly significant positive correlation with 
Table 1. Summary of the descriptive statistics of measured parameters in the study area

\begin{tabular}{|c|c|c|c|c|c|}
\hline Parameters & Units & Minimum & Maximum & mean $\pm \mathrm{Sd}$ & WHO (2008) limits \\
\hline $\mathrm{pH}$ & & 5.7 & 8.5 & $7.6 \pm 0.6064$ & $6.5-8.5$ \\
\hline Temp. & ${ }^{\circ} \mathrm{C}$ & 19.6 & 29.5 & $26.22 \pm 0.66$ & - \\
\hline Turbidity & NTU & 0.41 & 219 & $186.2 \pm 36.38$ & 5 \\
\hline $\mathrm{EC}$ & $\mu \mathrm{s} / \mathrm{cm}$ & 264 & 857 & $733 \pm 241.5$ & 1400 \\
\hline Salinity & $"$ & 0.00 & 0.30 & $0.131 \pm 0.140$ & - \\
\hline DO & $"$ & 2.01 & 6.40 & $5.25 \pm 0.916$ & - \\
\hline TDS & $"$ & 100.2 & 378 & $211.2 \pm 105.1$ & 1000 \\
\hline TA & $"$ & 480 & 1400 & $920 \pm 206$ & 500 \\
\hline $\mathrm{TH}$ & $"$ & 112 & 584 & $262 \pm 81.8$ & 100 \\
\hline COD & $"$ & 1 & 220 & $103 \pm 56.56$ & 10 \\
\hline Potassium & $\mathrm{mg} / \mathrm{L}$ & 4.15 & 14 & $8.9 \pm 2.665$ & 15 \\
\hline Sodium & $"$ & 26.03 & 200.4 & $107.4 \pm 50.51$ & 200 \\
\hline Nitrate & $"$ & 2.2 & 16.1 & $8.01 \pm 3.191$ & 50 \\
\hline Sulfate & $"$ & 4.2 & 115 & $102 \pm 37.79$ & 500 \\
\hline Chloride & $"$ & 14 & 250 & $140 \pm 66.5$ & 250 \\
\hline Iron & $"$ & 0 & 0.93 & $0.134 \pm 0.236$ & 0.3 \\
\hline Copper & $"$ & 0.0125 & 0.1805 & $0.042 \pm 0.034$ & 2 \\
\hline Zinc & $"$ & 0.11 & 0.28 & $0.160 \pm 0.035$ & 3 \\
\hline Cadmium & $"$ & 0 & 0.062 & $0.004 \pm 0.012$ & 0.003 \\
\hline Mercury & $"$ & 0 & 0.219 & $0.007 \pm 0.0346$ & 0.006 \\
\hline Lead & $"$ & 0 & 0.082 & $0.02 \pm 0.002$ & 0.01 \\
\hline
\end{tabular}

Here, Temp. $=$ Temperature; EC = Electrical conductivity; DO = Dissolve oxygen; TDS = Total dissolve solids; TA = Total alkalinity; $\mathrm{TH}=$ Total hardness; $\mathrm{COD}=$ Chemical oxygen demand.

salinity $(\mathrm{P}<0.001)$, chloride $(\mathrm{P}<0.001)$, sodium $(\mathrm{P}<0.001)$ and sulfate $(\mathrm{P}<0.01), \mathrm{COD}(\mathrm{P}<0.05)$. It is apparent from the table that salinity has a strong positive correlation with sodium $(\mathrm{P}<0.001)$, chloride $(\mathrm{P}<0.001)$, potassium $(\mathrm{P}<0.01)$, sulfate $(\mathrm{P}<0.01)$, and $\operatorname{COD}(\mathrm{P}<0.01)$. Sodium showed a strong correlation with potassium $(\mathrm{P}<0.001)$, chloride $(\mathrm{P}<0.001)$, sulfate $(\mathrm{P}<0.01)$ and $\mathrm{COD}(\mathrm{P}<0.05)$. Potassium was correlated with chloride $(\mathrm{P}<0.001)$ and sulfate $(\mathrm{P}<0.01)$. Chloride showed a positive relation with sulfate $(\mathrm{P}<0.01)$ and $\operatorname{COD}(\mathrm{P}<0.05)$. Iron showed a positive correlation with cadmium $(\mathrm{P}<0.05)$. Copper showed a positive correlation with mercury $(\mathrm{P}<0.001)$ and cadmium $(\mathrm{P}<0.001)$. Mercury showed a strong positive correlation with cadmium $(\mathrm{P}<0.001)$. The lead was also positively correlated with cadmium $(\mathrm{P}<0.01)$. In the current study, the person correlation analysis revealed similarities and differences of variables (Akoteyon and Soladoye, 2011). The variation in the correlation of different parameters shows the complexity of the water quality and also the effect of rock and water interaction (Giridharan et al., 2008). A strong positive significant correlation is a sign of a similar source while negative correlation is a sign of dissimilar source of origin for the parameters (Chabukdhara and Nema,
2012). Heavy metals such as cadmium, lead, copper and mercury directly enter to river environment by anthropogenic activities such as through urban discharge and metal processing industries effluents (Paul, 2017). Iron has no correlation with any parameter except cadmium that signifies dissimilar sediment properties (He et al., 2009). From the outcome, a strong confirmation of the common dependence of these heavy metals in the sediment coordination is predictable. The strong correlation among these variables may be due to weathering, improper sewage discharge and agriculture activities in the sampling area. In the present study a positive correlation among $\mathrm{pH}$ and $\mathrm{DO}(\mathrm{P}<0.05)$ indicates an increase in $\mathrm{pH}$ can limit the bacterial development that maintains DO level (Lara et al., 2017).

Cluster analysis. The levels of relationship at which interpretation are combined are used to build a dendrogram (Chen et al., 2007). The vertical axis in the dendrogram represents Euclidean distance and this is gives similarity among the clusters. The method (weighted pair group) is used and the Euclidean distance was chosen in the dendrogram as the measure of 


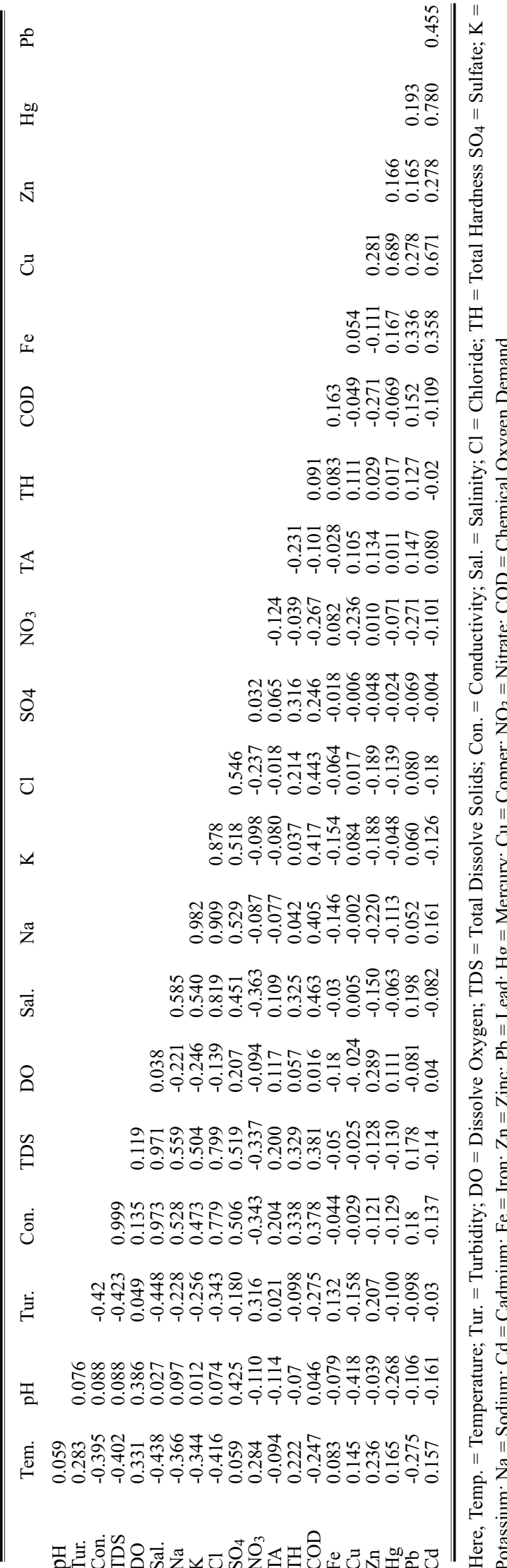

similarity. Kumar and Riyazuddin (2008) carried out Cluster Analysis (CA) of different variables in water samples. Hierarchical cluster analysis is a powerful tool to analyze hydrochemistry data (Yidana et al., 2008) and is an exploratory data examination tool used to find out different objects into groups. Similar objects are grouped in the same class in clustering analysis (Danielsson et al., 1999). The outcome of the cluster analysis is apparent in Fig. 2a. The figure demonstrates the dendrogram using agglomerative cluster analysis among seven parameters. The dendrogram revealed the formation of two major clusters. The first cluster consists of temperature, $\mathrm{pH}$, turbidity and $\mathrm{DO}$ while, the second cluster comprises salinity, TDS and conductivity. The dendrogram, which was derived from cluster analysis

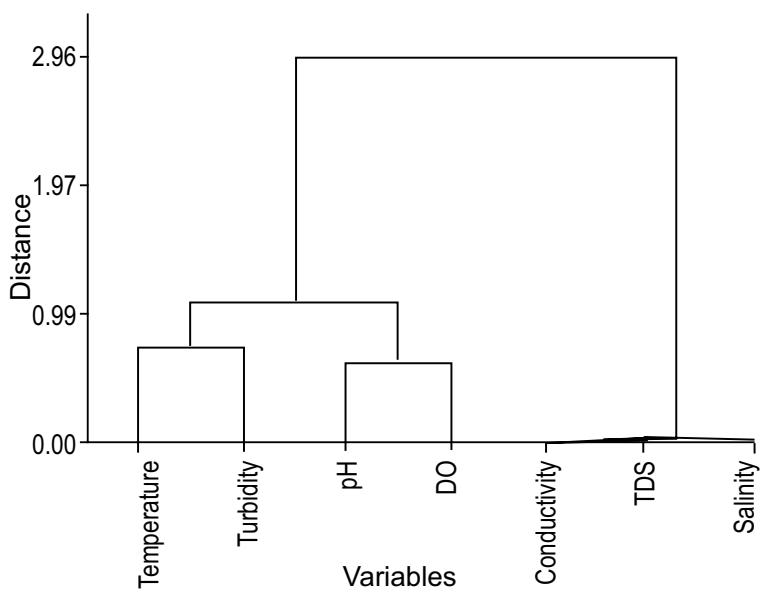

Fig. 2a. Dendrogram showing cluster analysis of physical parameters in the study area.

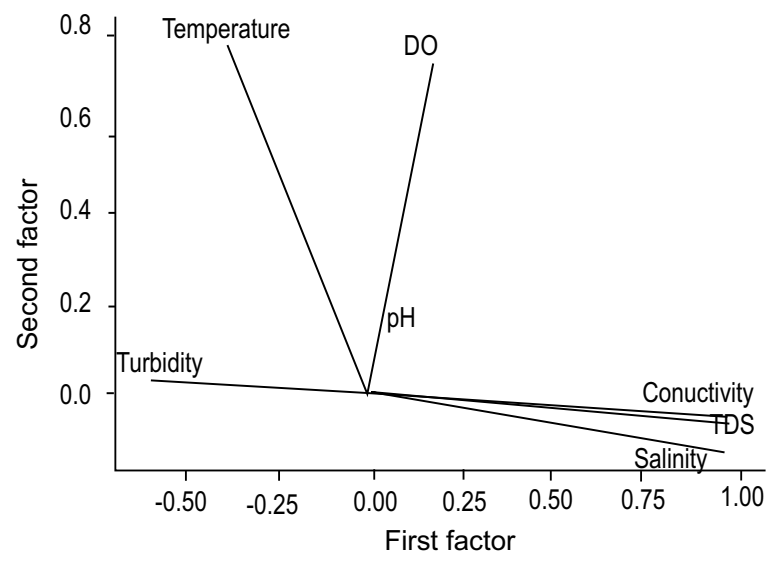

Fig. 2b. Plot ordination showing the varimax rotation of physical parameters in the study area. 
is performed for eight chemical parameters for samples is presented in Fig. 3a. The dendrogram exhibited two major clusters. The first cluster comprises of five parameters, namely, sodium, potassium, sulfate, chloride, and COD. The second cluster consists of only three parameters total hardness, total alkalinity and nitrate. The dendrogram, which was derived from cluster analysis, is performed for six heavy metals in the water samples is presented in Fig. 4a. The dendrogram exhibited two major clusters. The first cluster comprises of iron and lead while the second cluster consists of four parameters viz. copper, mercury, cadmium and zinc. The river Indus water passes through rocks comprising of bicarbonates, carbonates, calcium and magnesium ions causing hardness and alkalinity (Jain

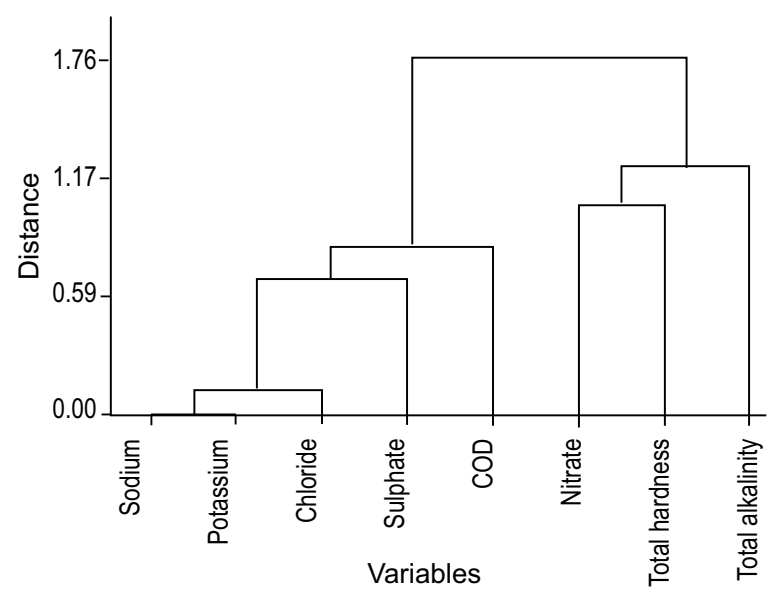

Fig. 3a. Dendrogram showing cluster analysis of chemical parameters in the study area.

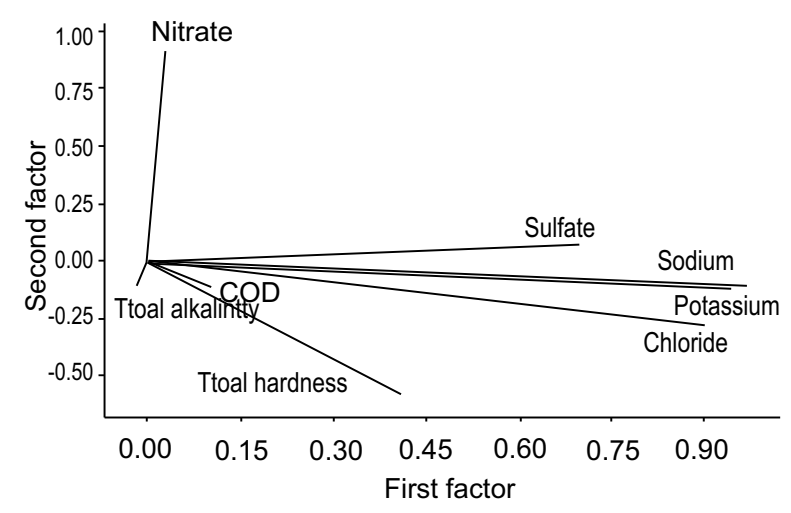

Fig. 3b. Plot ordination showing the varimax rotation of chemical parameters in the study area. et al., 2010). In the current study, the cluster analysis derived in the dendrogram for heavy metals recognized two main clusters that were analyzed as natural mineral components in the water samples and human-made based contamination (Xu et al., 2015).

Factor analysis using varimax rotation was performed to verify the results of cluster analysis of physical parameters (Fig. 2b). It is obvious from the figure that on the left side, a cluster of associated variables namely $\mathrm{pH}, \mathrm{DO}$, temperature and turbidity were formed. The second cluster was formed between three variables namely TDS, salinity and conductivity. Factor analysis of chemical parameters by using varimax rotation was performed to verify the results of cluster analysis of chemical parameters (Fig. 3b).

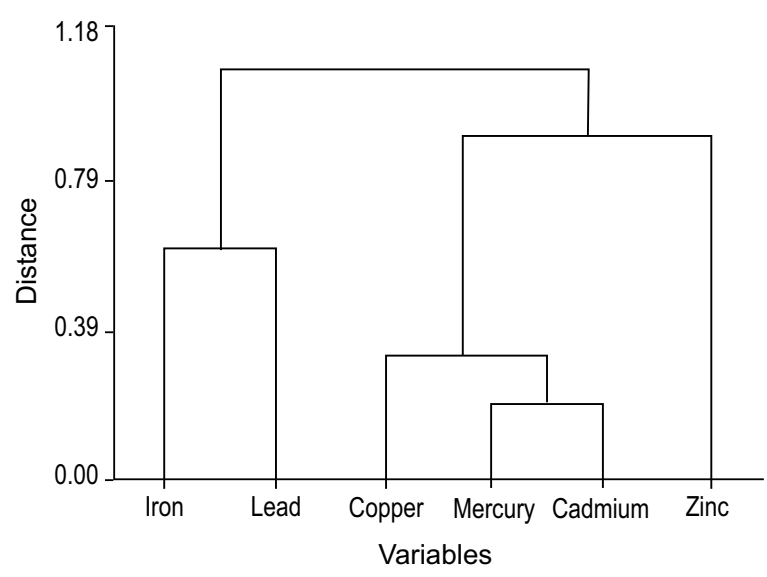

Fig. 4a. Dendrogram showing cluster analysis of heavy metal in the study area.

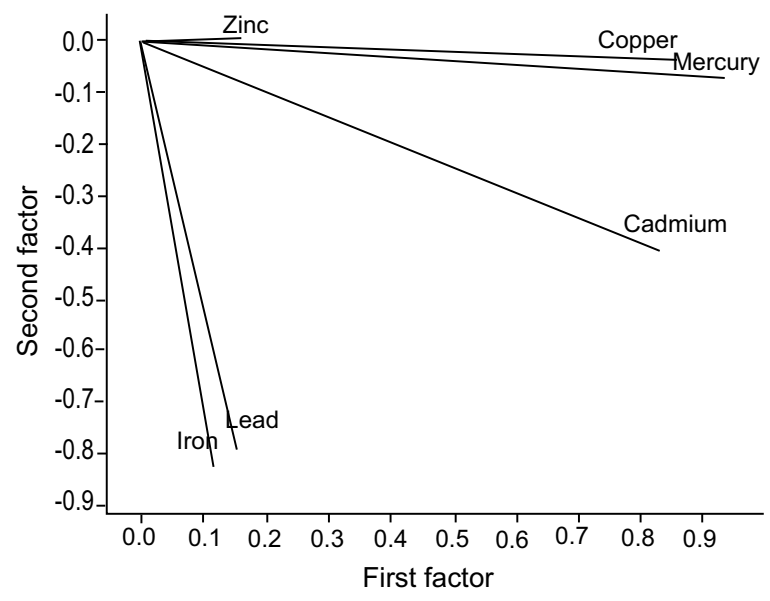

Fig. 4b. Plot ordination showing the varimax rotation of heavy metals in the study area. 
It is obvious from the figure that on the right side, a cluster of associated variables such as sodium, potassium, sulfate, COD and chloride was formed as observed in Cluster Analysis. The second cluster comprised of nitrate, total alkalinity, and total hardness. Figure $4 \mathrm{~b}$ showing the varimax rotation of heavy metals in the study area. It is obvious from the figure that on the right side, a cluster of associated variables namely mercury, copper, cadmium and zinc was formed as observed in cluster analysis. The second cluster was produced between iron and lead.

\section{Conclusion}

The current study revealed that the water of the sampling area has been polluted by several natural and anthropogenic activities. Findings from the statistical analysis such as Pearson correlation matrix and cluster analysis provided an approach to understand the controlling hydro chemical processes in river Indus and its tributaries. Tested parameters formed different clusters which showed the sign of weathering of rocks, agricultural runoff, municipal and industrial discharge that contaminate the river Indus. The concentration of several parameters such as heavy metals (lead, mercury, cadmium) and physico-chemical parameters (COD, total alkalinity, total hardness, turbidity) exceeded the permissible limits set by WHO (2008) guidelines for drinking water. The present investigation concluded that Indus river water in the sampling area has healthrelated risks. Appropriate laws should be implemented by environmental protection agency for the protection of water sources.

Conflict of Interest. The authors declare no conflict of interest.

\section{References}

Akoteyon, I.S., Soladoye, O. 2011. Groundwater quality assessment in Eti-Osa, Lagos-Nigeria using multivariate analysis. Journal of Applied Sciences and Environmental Management, 15: 121-125.

Azizullah, A., Khattak, M.N.K., Richter, P., Häder, D.P. 2011. Water pollution in Pakistan and its impact on public health - a review. Environment International, 37: 479-497.

Begum, T. 2011. Indus water treaty and emerging water issues. Abasyn University Journal of Social Sciences, 4: 265-288.

Capps, K.A., Bentsen, C.N., Ramírez, A. 2016. Poverty, urbanization and environmental degradation: Urban streams in the developing world. Freshwater Science, 35: 429-435.

Chabukdhara, M., Nema, A.K. 2012. Assessment of heavy metal contamination in Hindon river sediments: a chemometric and geochemical approach. Chemosphere, 87: 945-953.

Chen, K., Jiao, J.J., Huang, J., Huang, R. 2007. Multivariate statistical evaluation of trace elements in groundwater in a coastal area in Shenzhen, China. Environmental Pollution, 147: 771-780.

Danielsson, Å., Cato, I., Carman, R., Rahm, L. 1999. Spatial clustering of metals in the sediments of the Skagerrak/Kattegat. Applied Geochemistry, 14: 689-706.

De Fraiture, C., Wichelns, D. 2010. Satisfying future water demands for agriculture. Agricultural Water Management, 97: 502-511.

Giridharan, L., Venugopal, T., Jayaprakash, M. 2008. Evaluation of the seasonal variation on the geochemical parameters and quality assessment of the ground water in the proximity of river Cooum, Chennai, India. Environmental Monitoring and Assessment, 143: 161-178.

He, Z., Song, J., Zhang, N., Zhang, P., Xu, Y. 2009. Variation characteristics and ecological risk of heavy metals in the south Yellow sea surface sediments. Environmental Monitoring and Assessment, 157: 515-528.

Helena, B., Pardo, R., Vega, M., Barrado, E., Fernandez, J.M., Fernandez, L. 2000. Temporal evolution of ground water composition in an Alluvial Aquifer (Pisuerga river, Spain) by principal component analysis. Water Research, 34: 807-816.

Jain, C.K., Bandyopadhyay, A., Bhadra, A. 2010. Assessment of ground water quality for drinking purpose, district Nainital, Uttarakhand, India. Environmental Monitoring and Assessment, 166: 663-676.

Kalbus, E., Kalbacher, T., Kolditz, O., Krüger, E., Seegert, J., Röstel, G., Teutsch, G., Borchardt, D., Krebs, P. 2012. Integrated water resources management under different hydrological, climatic and socio-economic conditions. Environmenatal Earth Science, 65: 1363-1366.

Kumar, R.N., Solanki, R., Kumar, J.N. 2013. Seasonal variation in heavy metal contamination in water and sediments of river Sabarmati and Kharicut canal at Ahmedabad, Gujarat, India. Environmental Monitoring and Assessment, 185: 359-368. 
Kumar, A.R., Riyazuddin, P. 2008. Application of chemometric techniques in the assessment of groundwater pollution in a Suburban area of Chennai city, India. Current Science, 94: 1012-1022.

Lara, G., Krummenauer, D., Abreu, P.C., Poersch, L.H., Wasielesky, W. 2017. The use of different aerators on litopenaeus vannamei Biofloc culture system: effects on water quality, shrimp growth and Biofloc composition. Aquaculture International, 25: 147162.

Lashari, K.H., Sahato, G.A., Korai, A.L., Naqvi, S.H., Palh, Z.A., Urooj, N. 2012. Heavy metals Burden of Keenjhar lake, district Thatta, Sindh, Pakistan. African Journal of Biotechnology, 11: 12305 12313.

Memon, M., Soomro, M.S., Akhtar, M.S., Memon, K.S. 2011. Drinking water quality assessment in southern Sindh (Pakistan). Environmental Monitoring and Assessment, 177: 39-50.

Mitra, S., Kebbekus, B.B. 2018. Environmental Chemical Analysis, 344 pp. CRC Press, London, UK.

Paul, D. 2017. Research on heavy metal pollution of river Ganga: a review. Annals of Agrarian Science,
15: 278-286.

World Health Organization (WHO). 2008. Guidelines for Drinking-Water Quality $3^{\text {rd }}$ Edition, 668 pp. Incorporating the First and Second Addenda volume 1, Recommendations. World Health Organization, Geneva, Switzerland.

Wilhite, D.A., Sivakumar, M.V., Pulwarty, R. 2014. Managing drought risk in a changing climate: the role of National Drought policy. Weather and Climate Extremes, 3: 4-13.

Xu, G., Liu, J., Pei, S., Gao, M., Hu, G., Kong, X. 2015. Sediment properties and trace metal pollution assessment in surface sediments of the Laizhou Bay, China. Environmental Science and Pollution Research, 22: 11634-11647.

Yang, Y.C.E., Brown, C.M., Yu, W.H., Savitsky, A. 2013. An introduction to the IBMR, a hydroeconomic model for climate change impact assessment in Pakistan's Indus river basin. Water International, 38: 632-650.

Yidana, S.M., Ophori, D., Banoeng-Yakubo, B. 2008. A multivariate statistical analysis of surface water chemistry data - the Ankobra basin, Ghana. Journal of Environmental Management, 86: 80-87. 